\title{
Study on Possibility of Applying Risk Management in Village Fund Management in Landak Regency Indonesia
}

\author{
Fernandes Simangunsong, Amandus Ivo Mario \\ Institut Pemerintahan Dalam Negeri (Governmental Institute of Home Affairs), Bandung, Indonesia \\ Email: kisankiel@yahoo.co.id, fernandes_simangunsong@ipdn.ac.id, amandusivo1@gmail.com
}

How to cite this paper: Simangunsong, F. and Mario, A.I. (2018) Study on Possibility of Applying Risk Management in Village Fund Management in Landak Regency Indonesia. Open Journal of Social Sciences, 6, 271-297.

https://doi.org/10.4236/jss.2018.69019

Received: August 27, 2018

Accepted: September 23, 2018

Published: September 26, 2018

Copyright $\odot 2018$ by authors and Scientific Research Publishing Inc. This work is licensed under the Creative Commons Attribution International License (CC BY 4.0).

http://creativecommons.org/licenses/by/4.0/ (c) (i) Open Access

\begin{abstract}
This study is focused on study on possibility of applying risk management in village fund management in Indonesia. It is intended to determine the possibility of applying risk management in village fund management, the supporting and inhibiting factors in application of risk management, and strategies in implementation of risk management. Research design used was qualitative with exploratory approach. Data in this study were collected by interviewing the respondents (purposive sample), document study and field observation. Informants in this study are Regent of Landak, Regional Secretary of Landak Regency, Spokesperson of DPRD of Landak Regency, Head of Office of Social Service, Community Empowerment, and Local Government of Landak Regency, Head of Division of Village Financial and Asset Division, Head of Section of Village Government Budget, Chief of Karangan Village, Chief of Serimbu Village, and Chief of Amboyo Inti Village. The result demonstrates that process of implementing risk management in village fund management is limited to risk assessment, consisting of risk identification, risk analysis, and risk measurement, and then to build possibility of applying risk management using scenario planning which result in that it is possible to apply risk management by making regulations and preparing human resources. The supporting factors in applying risk management lie within political development aspect, and technological development aspect encourages the application of risk management. The inhibiting factors derive from individual threat, i.e. habits and fear of the unknown and organizational threat, i.e. Inertia Group. There are two approaches in preparing strategies for implementing risk management, i.e. top-down and bottom-up. And the strategies are making regulations on application of risk management, preparing human resources,
\end{abstract}


providing budget, providing facilities and infrastructures that support the application of risk management.

\section{Keywords}

Study on Possibility, Risk Management, Village Fund

\section{Introduction}

Village, as unit of legal community close to society with all backgrounds and needs, has vital role in national life of Indonesia. Government seriously promotes village as evidence of political promises Joko Widodo and Jusuf Kalla made during their presidential-vice presidential election campaign of 2016 [1]. Government issued a policy, i.e. Law No. 6 of 2014 on Village, to encourage village finances by Village Fund (Dana Desa $(D D)$ ). Table 1 shows projected and realized village fund in 2015-2016.

Table 1 shows considerable amount of Village Fund provided to Village Government, and it increases each year. Management of Village Fund that is poorly implemented will certainly cause problems. Until 2017, there were 110 cases of Village Fund misappropriation done by Village Chief [3]. Law Violation Cases in 2016 and 2017 consists of 734 cases of administrative error, 200 cases submitted to $K P K, 167$ cases submitted to police department, 50 cases of illegal charge, 201 cases of procedural error, 3113 cases of Village Fund misappropriation, and 1024 cases of Village Fund mismanagement and misuse.

In addition, among corruption cases that also occurred in West Kalimantan and East Java until 2017, there were alleged misappropriation of fund in 452 villages, fictitious activities in 214 villages, and irregular activities by 818 cases [4].

Similarly, corruption cases in Landak Regency, West Kalimantan Province can be seen in Table 2 .

According to Table 2, it is stated that there are several cases of village fund misappropriation in Landak Regency. It is mainly caused by village chief's lack of knowledge regarding the use of village fund.

In addition, other problem in management of village fund in Landak Regency

Table 1. Projected and realized village fund 2015-2016.

\begin{tabular}{lccc}
\hline & & \multicolumn{2}{c}{ Village Fund (in Rupiahs) } \\
\cline { 3 - 4 } No. & Description & 2015 & 2016 \\
\hline 1. & Projected Village Fund & Rp20,766,200,000,000.00 & Rp46,982,080,000,000.00 \\
2. & Realized & Rp18,216,110,640,000.00 & Rp45,878,001,120,000.00 \\
3. & Number of Village & 74,093 & 74,754 \\
4. & Amount of Fund per Village & Rp280,003,000,000.00 & Rp643,006,000,000.00 \\
\hline
\end{tabular}

Source: Explanation of Rural Development Policy by Ministry of Villages, Disadvantaged Regions and Transmigration [2]. 
Table 2. Number of corruption cases in management of village fund in Landak Regency, 2015-2016.

\begin{tabular}{ccl}
\hline No. & Year & \multicolumn{1}{c}{ Case } \\
\hline 1 & $\mathbf{2}$ & \\
\hline 1. & Cases in 2016 & $\begin{array}{l}\text { 1) Administrative error, 20 cases } \\
\text { 2) Submitted to } K P K, 1 \text { case }\end{array}$ \\
& $\begin{array}{l}\text { 1) Submitted to police, 4 cases of alleged misappropriation } \\
\text { 2) Alleged misappropriation of village fund by village chiefs, i.e. of } \\
\text { keranjipaidang village and parigi village } \\
\text { 3) Alleged abuse of authority, 4 cases, no village name disclosed } \\
\text { 4) Misappropriation of village fund by village chief, 1 case, money } \\
\text { had been returned }\end{array}$ \\
\hline
\end{tabular}

Source: 1) Data of Evaluation in Division of Village Financial and Asset (2018); 2) Data from Unit II investigator of Criminal Act of Corruption of Landak Police Precinct (2018).

is the late submission of Village Performance Documents, i.e. Document of Village Budget (APBDes), Document of Medium-term Village Development Planning (RPJMDes), Document of Village Government Work Plan (RKPDes), and Documents of Accountability Report, either Village Administration Report (LPPDes), Village Chief Accountability Report ( LKPj-Kades) and Information of Village Administration Report (ILPPDes) [5]. Furthermore, there is limited capability of the village in managing village fund because village apparatus are required to apply the use of village und according to rule [6]. Other regions also encounter same issues regarding management of village fund, as seen in Sanggau Regency where recently a case of village fund misappropriation occurs in 2 (two) of 163 villages [7].

There are considerable number of cases of village fund corruption that they potentially cause problems if not minimized. In management of village fund, there are many risks that can occur due to poor management. Risk is undesirable [8]. However, risk is also unavoidable part of individual and organizational work life, both in public and private sectors. Various risks in village financial management may occur, such as error in the implementation of activity that is not according to plan prepared by village.

It is a disadvantage when risk fails to be anticipated beforehand by individual or organization that can also threaten the achievement of purpose and objectives of the organization. Risk that is associated with uncertainty occurs due to lack of or unavailability of sufficient information regarding what may happen. Uncertain thing can be advantageous or disadvantageous.

Due to its uncertainty nature, risk needs to be managed. Risk in implementation of village fund that deviates from the planning can cause potential large loss and, if this continues to occur, it may cause more problems in public services, especially in rural regions.

Risk can be minimized or, even, eliminated by risk management. Risk management is expected to provide solution to handle risk that occurs unpredictably. Government has made regulation regarding risk management under Govern- 
ment Internal Control System (SistemPengendalian Intern Pemerintah (SPIP)), consisting of elements of Control Environment, Risk Assessment, Control Activities, Information and Communication, and Monitoring of Internal Control [9]. However, several regions failed to implement it since 2008. It is necessary to be applied, considering that village funds increase annually.

Village Fund $(D D)$ is fund sourced from State Budget $(A P B N)$ intended for villages, transferred via Regency/City Budget, and used for funding the administration of government, implementation of development, community development, and community empowerment [10]. It means that budget provided by government to village chiefs is to facilitate rural development and rural empowerment as village is a unit of legal community. The fund should be used and allocated in accordance with rules and regulations issued by government of Indonesia. Village Fund is expected to improve public services in villages, to reduce poverty, to improve rural economy, to minimize discrepancy of development between villages, and to consolidate rural people as the subject of development.

Commitment of Government to improve villages should not depend only on the availability of regulation but also on support from whole apparatus in order to achieve the purpose of improving and encouraging villages through the granting of village fund. For successful village financial management, it should be supported by village chief and village apparatus with good capacity. They should understand and grasp the content of regulation on village. Otherwise, village financial management will potentially suffer from serious problems in the future. Below, a Figure 1 regarding trend of educational background of village chiefs in Indonesia.

Based on data above, it is known that village chiefs are dominantly high school graduated, thus requiring special attention or otherwise would cause potential problems on village fund management. As for educational background of village chiefs in implementation of village fund management in Landak Regency, it can be shown in Table 3.

Explanation above suggests that most of village chiefs have high school (SMA) educational background. And according to the data above, there still are village

\section{Jenjang Pendidikan Kepala Desa}

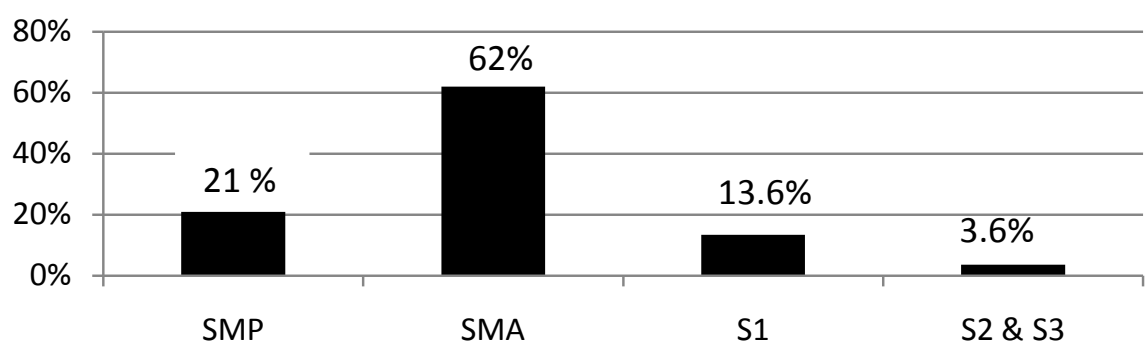

Figure 1. Educational Background of Village Chiefs. Source: Explanation of Rural Development Policy by Ministry of Villages, Disadvantaged Regions and Transmigration. 
Table 3. Village chief in Landak Regency by educational background in 2018.

\begin{tabular}{|c|c|c|c|c|c|c|c|c|}
\hline \multirow[b]{2}{*}{ No. } & \multirow[b]{2}{*}{ District } & \multirow[b]{2}{*}{$\begin{array}{c}\text { Number of } \\
\text { Village Chief }\end{array}$} & \multicolumn{6}{|c|}{ Education } \\
\hline & & & $\begin{array}{c}\text { Package B } \\
\text { Equivalency } \\
\text { Program }\end{array}$ & $\begin{array}{c}\text { Middle } \\
\text { School (SMP) }\end{array}$ & $\begin{array}{c}\text { High School } \\
(S M A) / \text { Vocational } \\
\text { High School (SMK) }\end{array}$ & $\begin{array}{c}\text { Package C } \\
\text { Equivalency } \\
\text { Program }\end{array}$ & D2/D3 & $\begin{array}{c}\text { Bachelor } \\
\text { Degree }\end{array}$ \\
\hline 1 & 2 & 3 & 4 & 5 & 6 & 7 & 8 & 9 \\
\hline 1. & Ngabang & 19 & - & 2 & 12 & - & 2 & 3 \\
\hline 2. & Sebangki & 5 & - & & 4 & - & & 1 \\
\hline 3. & Jelimpo & 13 & - & 1 & 10 & - & 1 & 1 \\
\hline 4. & SengahTemila & 14 & - & - & 10 & - & - & 4 \\
\hline 5. & Mandor & 17 & - & 2 & 10 & 2 & - & 3 \\
\hline 6. & Menjalin & 8 & - & - & 6 & - & - & 2 \\
\hline 7. & Mempawah Hulu & 17 & - & 4 & 10 & - & 1 & 2 \\
\hline 8. & Sompak & 7 & - & - & 6 & 1 & & \\
\hline 9. & Menyuke & 16 & - & 1 & 10 & 2 & 2 & 1 \\
\hline 10. & Banyuke Hulu & 7 & - & 2 & 5 & - & - & - \\
\hline 11. & Meranti & 6 & - & - & 4 & 1 & 1 & - \\
\hline 12. & Kuala Behe & 11 & 1 & 1 & 5 & 2 & 1 & 1 \\
\hline 13. & Air Besar & 16 & - & 2 & 9 & 2 & 1 & 2 \\
\hline & Total & 156 & 1 & 15 & 99 & 10 & 9 & 20 \\
\hline
\end{tabular}

Source: Data from Division of Village Office Administration and Village Apparatus Capacity Development (2018).

chiefs whose educational background are middle school (SMP). As stated in Law No. 6 of 2014 on Village, village apparatus shall has at least high school (SMA) or equivalent educational background. Therefore, with considerable amount of village fund, the lack of knowledge on its management will potentially create errors in using it.

Village government is not only to manage Village Fund sourced from State Budget $(A P B N)$, but also to manage Village Fund Allocation $(A D D)$, share of local tax and retribution, provincial financial aid and village own-source revenue (PADes). Regulatively, these whole financial affairs of village shall be documented in Village Budget (APBDes) which management follows several instructions from rules and regulations. Village Government can no longer manage village fund carelessly, despite the fact that authority as budget spender is in the hand of village chief.

Village financial management is whole activities consisting of planning, implementation, administration, reporting, and accountability of village finance. The first thing to consider is planning, because it is the basic requirement in village financial management. Village government is required to provide document of planning before managing village finance. There are three important documents of planning to be prepared by village government. Those are Medium-term Village Development Plan (RPJMDes), Village Government Work Plan (RKPDes), 
and Village Budget (APBDes). In terms of legality, these three documents are regulated in Regulation of Minister of Home Affairs No. 113 of 2014 on Village Financial Management, and Regulation of Minister of Home Affairs No. 114 of 2014 on Guidelines for Village Development and other related regulations on village. Without these documents, village government is not permitted to manage village finance. Imposing it without having these document will create problems in village financial management.

There are several issues in relation with village financial management. Corruption Eradication Commission ( $K P K$ ), in its study, found 14 issues of village fund, that potentially lead to corruption, under these top four aspects, i.e. regulation and institution, administration, control, and human resources. In aspect of regulation and institution, the issues are: 1) incomplete regulation and technical guidelines required in village financial management; 2) potential overlapping authority between Ministry of Villages, Disadvantaged Regions and Transmigration and Directorate General of Village Administration Development of Ministry of Home Affairs; 3) Formula for distribution of village fund under Government Regulation No. 22 of 2015 is insufficiently transparent and based only on equity; 4) distribution of fixed income for village apparatus shared from Village Fund Allocation under Government Regulation No. 43 of 2014 is unfair; and 5) obligation for preparing accountability report by village is inefficient due to overlapping regulations [11].

In the aspect of administration, there are five issues, i.e. 1) timeframe for cycle of village financial management is difficult to follow; 2) Standard price unit for goods/services used as reference by village in preparing Village Budget is still unavailable; 3) transparency of plan for using and accountability of Village Budget is still low; 4) accountability report made by village still deviate from standard and is prone to manipulation, one of reasons is due to ill-defined accounting system being used, and 5) Village Budget prepared is unable to fully include village's needs because it was not made in participatory manner.

As for the aspect of control, there are three issues, i.e. 1) regional inspectorate's effectiveness in the control of village financial management is still low; 2) public complaint channel is not managed well by all regions and there is no clear mechanism for submission of complaint; and 3) scope of evaluation and control by district head is still unclear.

Under the aspect of human resources, there is potential issue where assistant has potential for misappropriation by exploiting the lack of knowledge of village apparatus. This reflects on previous similar program, i.e., National Program for Community Empowerment (Program Nasional Pemberdayaan Masyarakat $(P N P M)$ ) for Village, where, instead of helping the community, the assistant did corruption and fraud.

Other problems are, such as, limited competent human resources in the making of medium-term regional development plan (RPJMD), Strategic Plan (Renstra), Work Plan (Renja), Village Budget (APBDes) that serve as reference in village administration. This weak planning results in poor performance of village 
government, because activities are not implemented based on analysis on village needs appropriately, and thus they do not give great impact on the community.

Based on data on-site, out of 156 villages in Landak Regency, only 10 villages have their Village Budget (APBDes) completed and Village Fund $(D D)$ as well as Village Fund Allocation $(A D D)$ in these 10 villages has been processed [12]. Furthermore, many supporting facilities and infrastructures are unavailable or limited, such as no electricity, damaged roads, broken bridge, unavailable cellphone signal and no land access for certain villages thus accessible only by river. With no electricity and difficult access of transportation, computerization of financial management is very difficult to be implemented [13].

Similarly, the facilities and infrastructures aforementioned are needed to support the success of office activities. Below, facilities and infrastructures owned by Office of Social Service, Community Empowerment and Village Administration of Landak Regency:

Data on Table 4 shows number of facilities owned by Office of Social Service,

Table 4. Inventory and equipment of office of social service, community empowerment and village administration of Landak Regency.

\begin{tabular}{|c|c|c|c|}
\hline Ordered No. & Name/Type of Item & Number of Item & Condition \\
\hline (1) & $(2)$ & (3) & $(4)$ \\
\hline 1 & Minibus & 1 & Good \\
\hline 2 & Motorcycle & 5 & Good \\
\hline 3 & Personal Computer & 10 & Good \\
\hline 4 & Archive Bookshelf & 3 & Good \\
\hline 5 & Laptop & 1 & Good \\
\hline 6 & Printer & 14 & Good \\
\hline 7 & Office Chair (Rakuda) & 31 & Good \\
\hline 8 & Office Table (Futura) & 11 & Good \\
\hline 9 & Office Chair (Foam Seat Cushion) & 8 & Good \\
\hline 10 & Filing Cabinet & 3 & Good \\
\hline 11 & Stabilizer & 10 & Good \\
\hline 12 & Calculator & 1 & Good \\
\hline 13 & Water Dispenser & 4 & Good \\
\hline 14 & Fan & 2 & Good \\
\hline 15 & Office Cabinet & 1 & Good \\
\hline 16 & Safebox & 1 & Good \\
\hline 17 & Archive Bookshelf & 1 & Good \\
\hline 18 & Teak Chair & 1 & Good \\
\hline 19 & Office Chair (Steel Frame, Foam Seat Cushion) & 2 & Good \\
\hline 20 & Whiteboard & 5 & Good \\
\hline
\end{tabular}

Source: Strategic Plan of DSPMPDes of Landak Regency, 2017. 
Community Empowerment and Village Administration (DSPMPDes) of Landak Regency to support administrative affairs in social area, community empowerment and village administration.

Similarly, author also shows facilities owned by Village as follows:

Data (Table 5) suggests that office facilities and infrastructures in Amboyo Inti Village, Serimbu Village and Karangan Village are still limited, as can be seen that village hall, official residence of village chief, official residences of village apparatus, clean water, telephone, fax machine, and official vehicle are still unavailable. And other facilities and infrastructures are already available.

Based on Government Regulation No. 18 of 2016 on Local Agencies, article 36 , clause 2 , it is stated that duty of regency/city type $\mathrm{A}$ is to facilitate the implementation of official function of regency/city with great responsibility. Furthermore, in Regional Regulation No. 5 of 2016 on Formation and Structure of Local Agencies of Landak Regency, Article 3, it is stated that Office of Social Service, Community Empowerment and Village Administration of type A implements administrative affairs in social area, community and village empowerment area. It means that Office of Social Service, Community Empowerment and Village Administration (DSPMPDes) has great responsibility in administrative affairs in social area and administrative affairs in community and village empowerment

Table 5. Inventory of facilities and infrastructures in Amboyo Inti Village, Serimbu Village, and Karangan Village, 2017.

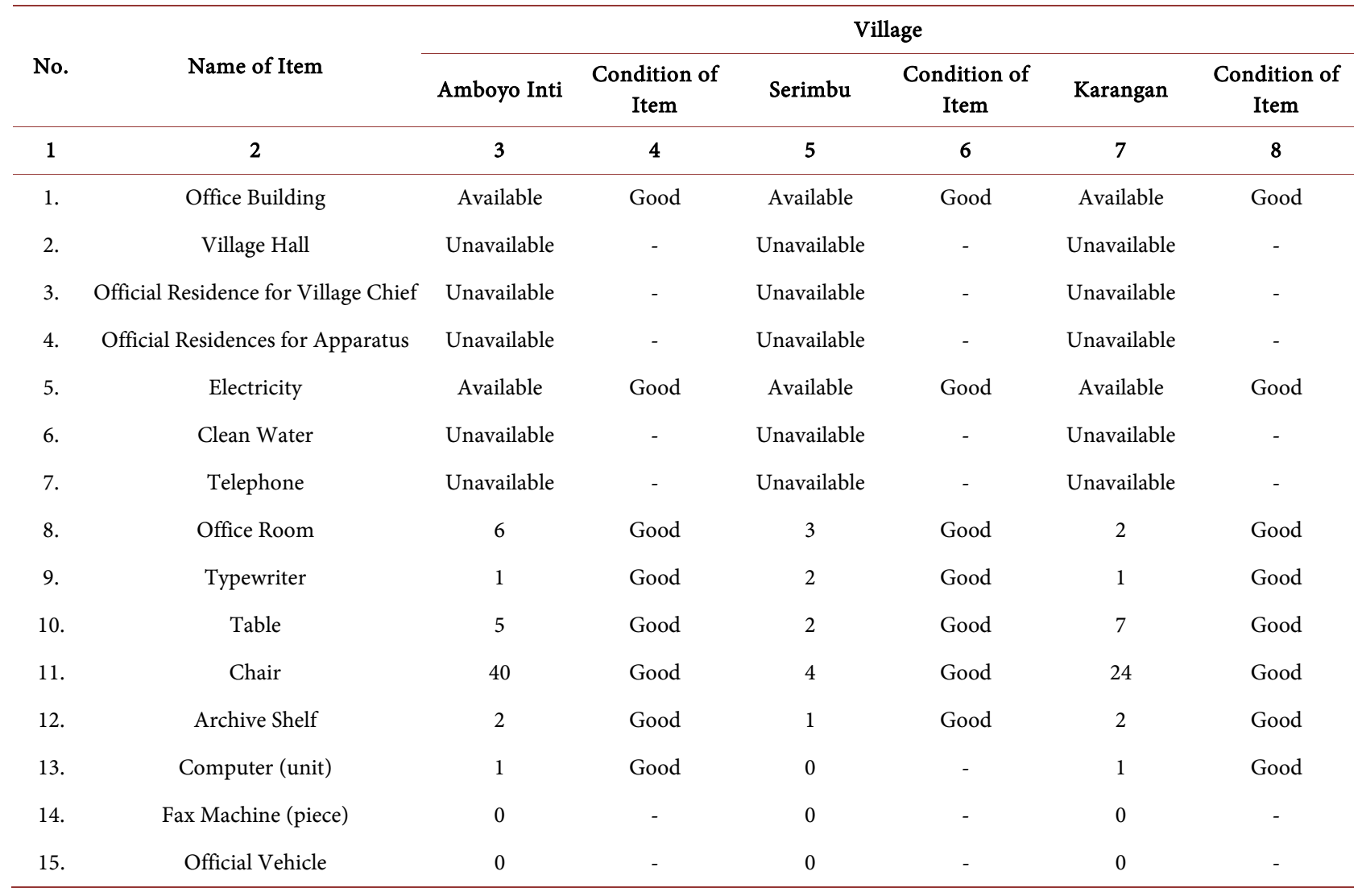

Source: Profile of VillageLandak Regency, 2017. 
area. Office of Social Service, Community Empowerment and Village Administration has great responsibility in implementation of social affairs and administrative affairs in community and village empowerment and requires human resources capable of holding main duties and functions in appropriate, immediate, and elaborate manner according to the plan. Human resources is one of vital factors to run organizational activities to achieve its purpose. Ideally, number and competence of human resources should be appropriate with organizational needs. Currently, number of State Civil Servant $(A S N)$ under the Office of Social Service, Community Empowerment and Village Administration of Landak Regency is 15 people, with detail by the status is as follows:

From Table 6, it can be seen that number of human resources in Office of Social Services, Community Empowerment and Village Administration by $71.43 \%$ or 15 people are already in status of civil servant (PNS). And $28.57 \%$ or 6 people are in status of honorary staff. Total number of personnel is 21 . The distribution of civil servants is as follows: the highest number is under Division of Secretariat by 5 , followed by Division of Village Administration by 4, Division of Community Empowerment by 3, and Division of Social Institution Empowerment by 1 . The high number of personnel in the Secretariat Division indicates the important role of Office of Social Service, Community Empowerment and Village Administration as an institution with function to serve public needs.

Description of number of State Civil Servant under the Office of Social Service, Community Empowerment and Village Administration (DSPMPDes) as in Table 7 shows that educational background of staff of Office of Social Service, Community Empowerment and Village Administration consisting of Master Degree (S2) by 1 person or 6.66\%, followed by Bachelor Degree (S1) by 6 persons or $40.00 \%$, Associate Degree (Diploma) by 2 persons or $13.33 \%$ and High School $(S M A)$ by 6 persons or $40.00 \%$. Information based on the data is that human resources in Office of Social Service, Community Empowerment and Village Administration is still insufficient to handle 156 villages in Landak Regency. In addition, there is only limited number of $A S N$ with skill in information technology.

Table 6. Number of ASN per division by personnel status in Landak Regency, 2011-2016.

\begin{tabular}{cccccc}
\hline & \multicolumn{5}{c}{ Division } \\
\cline { 2 - 5 } Status & Secretariat & $\begin{array}{c}\text { Village } \\
\text { Administration }\end{array}$ & $\begin{array}{c}\text { Community } \\
\text { Empowerment }\end{array}$ & PLK & Total \\
\hline 1 & 2 & 3 & 4 & 5 & 6 \\
\hline $\begin{array}{c}\text { Civil Servant } \\
\text { Civil Servant }\end{array}$ & 5 & 4 & 5 & 1 & 15 \\
$\begin{array}{c}\text { Candidate/Honorary } \\
\text { Number per Division }\end{array}$ & 3 & - & 2 & 2 & 6 \\
$\begin{array}{c}\text { Percentage of } \\
\text { Distribution }\end{array}$ & 38.10 & 19.05 & 33.33 & 9.52 & 100 \\
\hline
\end{tabular}

Data Source: Strategic Plan of DSPMPDes of Landak Regency, 2017-2022. 
Table 7. Number of ASN under office of social service, community empowerment and village administration by rank in Landak Regency, 2011-2016.

\begin{tabular}{|c|c|c|c|c|c|c|c|c|c|c|c|}
\hline \multirow{2}{*}{ No } & \multirow{2}{*}{ Echelon/Non-Echelon } & \multicolumn{6}{|c|}{$\begin{array}{l}\text { Office of Social Service, Community Empowerment and Village } \\
\text { Administration }\end{array}$} & \multicolumn{4}{|c|}{ Rank } \\
\hline & & $\begin{array}{c}\text { Master } \\
\text { Degree } S 2\end{array}$ & $\begin{array}{l}\text { Bachelor } \\
\text { Degree } S 1\end{array}$ & $D 3$ & $S M A$ & $S M P$ & $S D$ & IV & III & II & I \\
\hline 1 & 2 & 3 & 4 & 5 & 6 & 7 & 8 & 9 & 10 & 11 & 12 \\
\hline 1. & II & 1 & - & - & - & - & - & 1 & - & - & - \\
\hline 2. & III & - & 3 & - & 1 & - & - & - & 4 & - & - \\
\hline 3. & IV & - & 1 & 1 & - & - & - & - & 2 & - & - \\
\hline & Subtotal & 1 & 4 & 1 & 1 & - & - & 1 & 6 & - & - \\
\hline & Non-Echelon & - & 2 & 1 & 5 & - & - & - & 3 & 5 & - \\
\hline & Total & 1 & 6 & 2 & 6 & - & - & 1 & 9 & 5 & - \\
\hline & Percentage (\%) & 6.66 & 40 & 13.3 & 40 & & & & & & \\
\hline
\end{tabular}

Data Source: Strategic Plan of DSPMPDes of Landak Regency, 2017-2022.

Furthermore, to implement improvement on village, support of budget for Office of Social Service, Community Empowerment and Village Administration (DSPMPDes) is necessary, which amount is incorporated in Local Budget of LandakRegency. Local Budget ( $A P B D$ ) of Landak Regency 2015-2016 was still deficit. The data can be seen in Table 8.

Local Budget $(A P B D)$ of Landak Regency 2015 consisted of Local Revenue by Rp963,510,588,764.38 was not proportional to Local Expenditures of Rp1,061,581,314,689.15, thereby deficit by Rp98,070,725,924.77 [14]. Furthermore, Local Budget $(A P B D)$ of Landak Regency 2016 consisted of Local Revenue by Rp1,289,255,217,205.00, and Local Expenditures by Rp1,369,130,981,143.02, thereby deficit by Rp79,875,763,938.02 [15].

The great amount of personnel expenditure in indirect expenditures resulted in minimum capital expenditure and goods and service expenditure in direct expenditures, and thereby program and purchase of facilities and infrastructures by Local Bureaucracy (OrganisasiPerangkat Daerah $(O P D)$ ) were still unaccommodated. Table 9 shows amount of budget for purchase of facilities and infrastructures:

Data in Table 9 suggests that the amount of budget to improve facilities and infrastructures of government agencies in Office of Social Service, Community Empowerment and Village Administration is still insufficient for purchase of computer and its equipment, chairs and tables, making of website, maintenance of building, and maintenance of operational vehicle to provide service to 156 villages in Landak Regency, thus it needs more budget in 2018.

On the other side, amount of Village Fund for Landak Regency increases each year, thus support from Office of Social Service, Community Empowerment and Village Administration (DSPMPDes) is necessary. Table 10 shows amount of Village Fund for Landak Regency. 
Table 8. Local budget of Landak Regency, 2015-2016.

\begin{tabular}{cccc}
\hline & \multirow{2}{*}{ No. } & \multicolumn{2}{c}{ Local Budget of Landak Regency (in Rupiahs) } \\
\cline { 3 - 4 } & Description & 2015 & 2016 \\
\hline 1 & 2 & 3 & 4 \\
\hline 1. & Local Revenue & $963,510,588,764.38$ & $1,289,255,217,205.00$ \\
2. & Local Expenditures & $1,061,581,314,689.15$ & $1,369,130,981,143.02$ \\
3. & Surplus/(Deficit) & $(98,070,725,924.77)$ & $(79,875,763,938.02)$ \\
\hline
\end{tabular}

Source: Regional Regulation of Landak Regency on Local Budget 2015 and 2016

Table 9. Amount of budget agencies' facilities and infrastructures improvement program from 2015 to 2017.

\begin{tabular}{cccc}
\hline No. & Year & Total & \% Increase \\
\hline 1 & 2 & 3 & 4 \\
\hline 1. & 2015 & $169,500,000$ & $0 \%$ \\
2. & 2016 & $246,475,000$ & $68.77 \%$ \\
3. & 2017 & $131,749,750$ & $(-87 \%)$ \\
\hline
\end{tabular}

Source: Strategic Plan of Landak Regency, 2017-2022.

Table 10. Amount of village fund in Landak Regency, 2015-2018.

\begin{tabular}{cccc}
\hline No. & Year & Total & \% Increase \\
\hline 1 & 2 & 3 & 4 \\
\hline 1. & 2015 & Rp53,881,652,528.00 & $10.7 \%$ \\
2. & 2016 & Rp131,491,688,624.03 & $144.03 \%$ \\
3. & 2017 & Rp128,000,000,000.00 & $(-) 2.6 \%$ \\
4. & 2018 & Rp150,928,818,000.00 & $15.19 \%$ \\
\hline
\end{tabular}

Source: Regional Regulation on Local Budget 2015, 2016, 2017, and 2018.

Table 10 shows that village financial aid given each year increases, with amount of Rp53,881,652,528.00 in 2015, Rp131,491,688,624.03 in 2016, Rp128,000,000,000.00 in 2017, and Rp150,928,818,000.00 in 2018. With number of village in Landak Regency by 156 villages and distribution of village fund by number of population, poverty rate, area size, and geographical difficulty rate, each village receives fund by approximately Rp800 million, meaning more budget for village that requires effective risk management to minimize undesirable risk to occur.

Without sufficient managerial skills, bureaucrats will only become puppet in political play without clear and strong sense of self. Therefore, every bureaucrat should master management aspect in order to achieve organizational purpose, so that any risk that hinder organizational purpose can be minimized [16].

Government organizations are established with vision and missions to achieve purpose according to the plan, and so are local government organizations. In 
order to achieve vision and missions of the local government organizations, program and activities are planned to avoid potential failure of achieving the purpose.

Annually Increasing amount of village fund $(D D)$ in implementation of development of Indonesia from peripheral areas is to strengthen regions and villages within the framework of unitary State [17]. This is confirmed by issuance of Law No. 6 of 2014 on Village, along with determination of prioritized use of village fund every year. Village fund, applied from 2014 until now, poses many risks that burden village apparatus and local agencies from its planning, implementation, administration, reporting to accountability. The risks resulted from the use of village fund should be counterbalanced by improving risk management, so that the risk can be minimized. In order to minimize risks faced by organization to achieve its purpose, government has enacted Government Regulation No. 60 of 2006 on Government Internal Control System (SistemPengendalian Intern Pemerintah (SPIP)) in which Article 13 clause (1) and (2) it is stated that: "Head of government institutions shall be required to perform risk assessment, consisting of risk identification and risk analysis". Risk Management in the sector of Government is more known as Government Risk Management (GRM).

The Government Regulation clearly suggests that government institutions are required to perform risk assessment, i.e. risk identification and risk analysis, and make a control structure to handle the risks. Impacts desired by enactment of this Government Regulation No. 60 of 2008 actually are Financial and Performance Accountability. However, after almost nine years since enactment of the regulation, only a limited number of government institutions have applied risk management within organizational environment, either in terms of legal aspect or the implementation. Whereas it is stated in the Medium-term National Development Plan (RPJMN) that ministries/agencies and Local Government in Indonesia are required to apply Government Internal Control System (SPIP) and should implement internal audit effectively marked by level 3 in 2019 [18].

Risks occur in management actions that make use of existing human resources and operational process of the control activities. Risk that is not handled shall affect the success of local organization to achieve its purpose. Therefore, heads and staff of organizational units must be responsible on issues or risks they will face and on activities they are either able or unable to implement in order to achieve the purpose. Organizational activities of local agencies are also influenced by internal and external factors. Internal factors are work environment and operational method, and external factors are change of democratic climate, political climate and change of regulation.

Therefore, author offers Risk Management in village fund management to handle risks occur in the processes of planning, implementation, administration, reporting and accountability of the use of village fund. In Risk Management, author specifically limit it on risk assessment because "risk assessment is the 
fundamental activity of risk management, meaning that risk management tools, techniques and strategies cannot be applied until an organization identifies and understands its risks”. Risk assessment consists of Risk Identification, Risk Analysis, and Risk Measurement After risk assessment, the next is determining possibilities in the application of risk management in the Office of Social Service, Community Empowerment and Village Administration (DSPMPDes) of Landak Regency, because it has never been implemented before in Landak Regency, especially for village fund management [19].

Based on elaboration above, author is intrigued to carry out a study titled "Study on Possibility of Applying Risk Management in Village Fund Management in Indonesia".

\section{Problem Statement}

Based on issues identified, author has formulated problems to study as follows:

1) How is the possibility of applying risk management in village fund management in Indonesia?

2) What are the supporting and inhibiting factors for application of risk management in village fund management in Indonesia?

3) What are strategies to handle the inhibiting factors for application of risk management in village fund management in Indonesia?

\section{Theoretical Framework}

In rural development, village receives fund from central government by using State Budget $(A P B N)$. This is stated in Law No. 6 of 2014 on Village that one of sources of village revenue is from allocation of State Budget [20]. Furthermore, it is clarified by Government Regulation No. 60 of 2014 on Village Fund sourced from State Budget, stating that Government prepares budget for village fund nationally in State Budget $(A P B N)$ every year [21]. With fund sourced from State Budget $(A P B N)$, it is expected to be able to develop villages in accordance with program of the government of Indonesia, i.e. to develop Indonesia from peripheral regions that have been under disadvantaged status [22].

To achieve the purpose of developing villages through Village Fund, it is important to determine risks that potentially occur when managing Village Fund. In order to be able to make appropriate decision in village fund management by considering the risks, it requires risk management. Without good management, misappropriation and administrative error have occurred, with 734 cases of administrative errors, 201 cases procedural error, 3113 cases of village fund corruption, and 50 cases of illegal charge. Cases of misappropriation done by village chiefs also happens in West Kalimantan, where two village chiefs among 163 villages are suspected in village fund corruption case [23].

In Government Regulation No. 60 of 2008 on Government Internal Control System (SPIP), it is stated that internal control consists of interconnected five elements: Control Environment, Risk Assessment, Control Activity, Information 
and Communication, and Monitoring. Internal control framework above suggests that it requires risk management in village fund management. In addition to several elements of risk management aforementioned, there are also risk management elaborated in the book of Public Sector Risk Management, i.e. Mission identification, risk and uncertainty assessment, risk control, risk financing, programme administration.

Due to many elements in Risk Management, author specifically limit it on risk assessment by which defined as fundamental activity of risk management. Risk assessment is the fundamental activity of risk management, meaning that risk management tools, techniques and strategies cannot be applied until an organization identifies and understands its risks. Risk assessment consists of Risk Identification, Risk Analysis, and Risk Measurement.

Risk management in village fund management is intended to minimize risk to occur. Village fund management has been regulated in Regulation of Minister of Home Affairs No. 113 of 2014 on Village Financial Management stating that village fund management consists of planning, implementation, administration, reporting and accountability. Each stage in village fund management certainly has risk that has never been handled, while risk management that has been done was only in general by following existing regulation and not in specific. Furthermore, in Landak Regency, village financial management is regulated in Regent Regulation No. 3 of 2016 on Village Financial Management.

The use of village fund should consider priority for every year, so that the purpose to develop the village is measurable and things to be prioritized can also be determined appropriately. Priority of the use of village fund is regulated in Regulation of Minister of Villages, Disadvantaged Regions and Transmigration No. 5 of 2015 on Priorities in the Use of Village Fund 2015, Regulation of Minister of Villages, Disadvantaged Regions and Transmigration No. 21 of 2015 on Priorities in the Use of Village Fund 2016, and Regulation of Minister of Villages, Disadvantaged Regions and Transmigration No. 22 of 2016 on Priorities in the Use of Village Fund 2017. Author limits the scope on only last three years, i.e. 2015, 2016, and 2017.

Furthermore, application of risk management in public sector requires support in its implementation. The supporting factors in the application of risk management are nature of workplace, technology, economic shock, competition, social trend and world politics. And with support in applying the risk management to government organizations, it is expected to find solution to determine the risks and to provide input on decision in village fund management.

In addition, in application of risk management, there is a possibility of organizational resistance against change of management carried out by head of institution when applying risk management. As for the inhibiting factors, there are individual resistance, consisting of habits, security, economic factor, fear of the unknown, selective information processing, and organizational resistance, consisting of structural inertia, limited focus of change, group inertia, threat to expertise, threat to established power relationship, and threat to established re- 
source allocation [24].

Then, strategy of applying risk management can be performed in two approaches by head of the institution, i.e. Top-Down and Bottom-Up. These approaches are expected to serve as strategy in implementation of applying risk management in government organizations [25].

Application of risk management in government organization is focused on village fund management in the Office of Social Service, Community Empowerment and Village Administration (DSPMPDes). Office of Community Empowerment and Village Administration (BPMPDes) has been changed into Office of Social Service, Community Empowerment and Village Administration (DSPMPDes) after the enactment of Government Regulation No. 18 of 2016 on Local Bureaucracy. According to Regional Regulation of Landak Regency No. 5 of 2016 on Formation and Structure of Local Agencies of Landak Regency, it is stated that DSPMPDes of type A implements administrative affairs in social area and administrative affairs in community and village empowerment area, which means that Office of Social Service, Community Empowerment and Village Administration has great workload to implement those affairs and thus requires special attention [26].

Increased amount of village fund given by transfer of village fund to local account is regulated in Presidential Regulation No. 36 of 2015 on Details of State Budget 2015, Presidential Regulation No. 137 of 2015 on Details of State Budget 2016, and Presidential Regulation No. 86 of 2017 on Details of State Budget 2017. Furthermore, distribution of village fund has undergone several changes:

1) Year 2015

Distribution of village fund was done in 3 stages, i.e. first stage was on April by $40 \%$, and second stage was on August by $40 \%$ and third stage on October by $20 \%$. The distribution of village fund was regulated in Regulation of Minister of Finance No. 93/pmk.07/2015.

\section{2) Year 2016}

Distribution of village fund was done in 2 stages, i.e. first stage was on March by $60 \%$, and second stage was on August by $40 \%$. The distribution of village fund was regulated in Regulation of Minister of Finance No. 49/pmk.07/2016.

3) Year 2017

Distribution of village fund was done in 3 stages, i.e. first stage was, at soonest, on January and, at latest, on 3rd week of June by $20 \%$, second stage was, at soonest, on March and, at latest, on June by $40 \%$, and third stage was at soonest on July by $40 \%$.. The distribution of village fund was regulated in Regulation of Minister of Finance No. 225/pmk.07/2017 [27].

Determination of the amount of village fund considers population size, poverty rate, area size, and geographical difficulty rate which is regulated in Regulation of Ministry of Finance No. 49/pmk.07/2016. Based on support of theoretical and normative bases and condition on-site, and through theoretical exploration processed into conceptual reference of research variables, a theoretical framework can be set as Figure 2 as follows. 


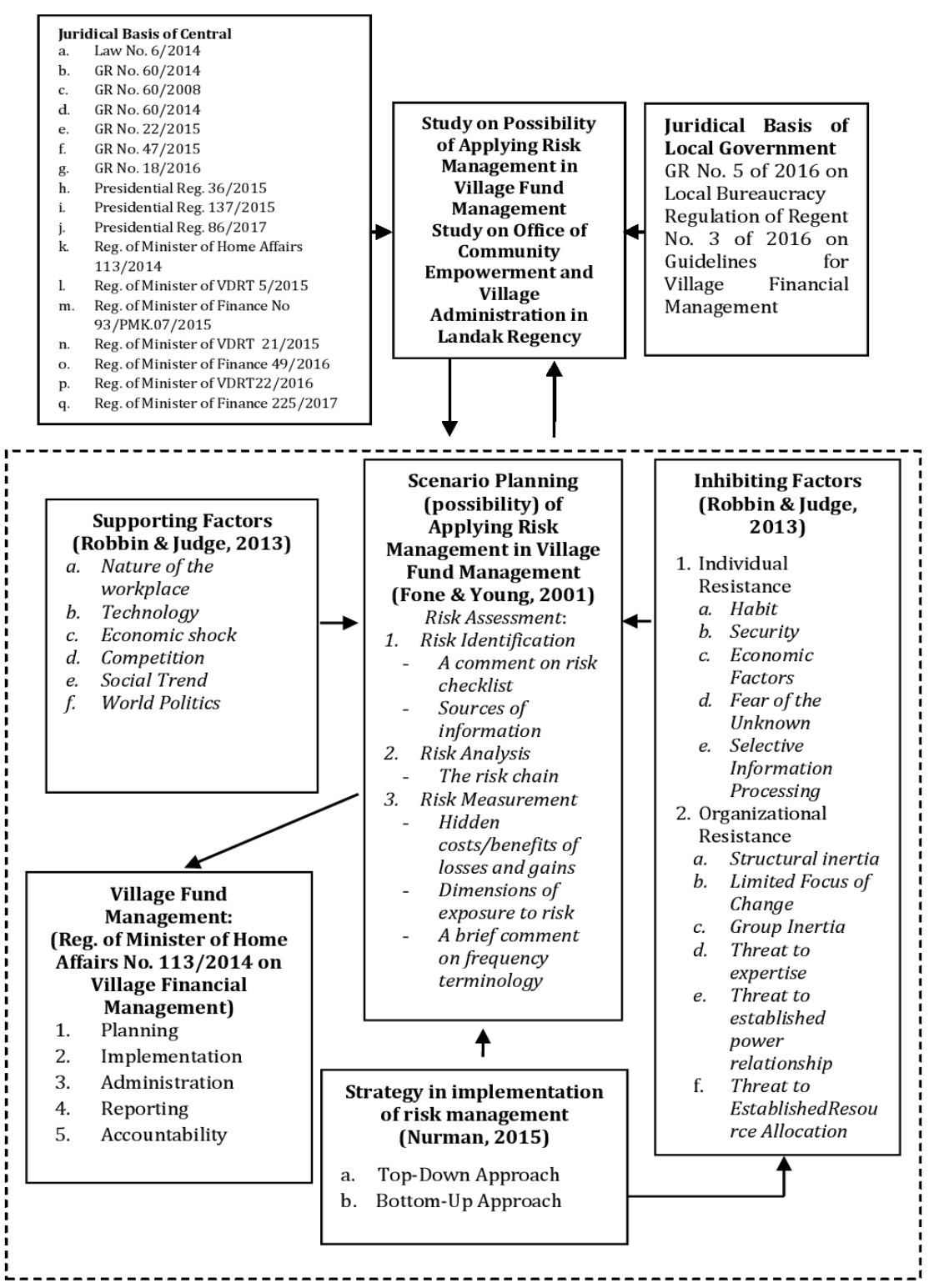

Sources: 1. Fone and Young, Public Sector Risk Management (2001).

2. Nurman, M.Si., Ph.D., Strategi Pembangunan Daerah (Regional Development Strategy) (2015).

3. Stephen P. Robbins and Tymothy A. Judge. Organizational Behavior (2013).

Figure 2. Theoretical framework.

\section{Work Hypothesis}

Implementation of risk management can be performed in village fund management through stages of risk assessment, i.e. Risk Identification, Risk Analysis, and Risk Measurement.

\section{Research Method}

Author intends to conduct exploratory research by considering administrative phenomena currently happening. Administrative research conducted with object of village fund management is expected to answer all issues discussed in this 
study. Administrative research means an effort to find, develop and test administrative symptoms, phenomena and dynamics in order to determine truth in public administration science within context of authority and public services in coherent, correspondent, and pragmatic manners, set out from systematic thinking with theoretic, legalistic, empiric, and innovative advantages [28].

Considering that this exploratory research is related to a condition or situation or thing that has never occurred or been done before, there is a right method to be used to analyze the issues, i.e. scenario planning. "Scenario Planning is an asset in that it has brought about a variety of interpretations about what scenario planning is" [29]. In addition, other definition of scenario planning is an effective futuring tool that enables planners to examine what is likely and what is unlikely to happen, knowing well that unlikely elements in an organization are those that can determine its relative success [30].

Theoretical process is closely related to activity to explain on the problems using relevant theory and to build conceptual framework to be used in research. With conceptual framework, research will be more focused to find the root of problems. Therefore it is important to make conceptual framework so that the research will more focused. And definition of operational concept is that "Operationalization in qualitative research is detailed description of how a researcher collected and thought about the specific data that become the basis for concepts. Qualitative operationalization describes how researcher collect data" [31].

Elaboration above suggests that operational definition of researcher's concept can be made by providing detailed explanation on a concept by using collected data and thinking related to data specifically used as basis for the concept. Research is conducted to determine the possibility of applying risk management in village fund management in order to make policy regarding village fund management so that the risks can be managed properly, knowing that poor management of village fund will cause problems, both individual and organizational, thus it is necessary to handle inhibiting factors in application of risk management.

In the conceptual framework of this study, author elaborates the concept broken down into more detailed themes and sub-themes to be used as guide in interview. This step is intended to facilitate author to analyze existing problems and to find solution for the problems. As shown in Table 11.

Data required in this study was primary data obtained from informants through interview, focused discussion, and questionnaire and poll. And the secondary data was obtained from Regional Data in Numbers, issued by Statistics Indonesia (Biro PusatStatistik (BPS)), books, reports, journals, proceedings, etc. According to Simangunsong, "In qualitative research of public administration, informant is vital, not merely to provide response, but also to serve as source of accurate information and is admittedly considered capable of giving information comprehensively and worth to ask for information" [32].

In this study, the key informant is Regent of Landak, who serves as policy 
Table 11. Operational conceptual.

\begin{tabular}{cccc}
\hline No. & Theme & Subtheme & Sub-subtheme \\
\hline 1 & 2 & 3 & 4 \\
\hline
\end{tabular}

Study on Possibility of Applying Risk Management in Village Fund Management in Landak Regency, West Kalimantan

1. Province (Study on Office of Social Service, Community Empowerment and Village Administration) (Fone \& Young, 2001)

Supporting and Inhibiting Factors in the Study on Possibility of Applying Risk Management in Village Fund Management

2. in Landak Regency, West Kalimantan Province (Study on Office of Social Service, Community Empowerment and Village Administration). (Robbins and judge, 2013)

\section{Risk Identification}

Risk analysis

Risk Measurement
1) A comment on risk checklist

2) Sources of Information

1) The risk chain

1) Hidden costs/ benefits of losses and gains

2) Dimensions of exposure to risk

3) A brief comment on frequency and magnitude measurement terminology

a) Nature of the workplace

b) Technology

Supporting factors (Robbins and

c) Economic shock Judge, 2013):

d) Competition

e) Social Trend

f) World Politics

Inhibiting factors

(Robbins and Judge, 2013):

a) Habit

b) Security

1) Individual Resistance

c) Economic Factors

d) Fear of the Unknown

e) Selective Information Processing

a) Structural inertia

b) Limited Focus of Change

c) Group Inertia

2) Organizational Resistance

d) Threat to expertise

e) Threat to established power relationship

f) Threat to Established Resource Allocation

Strategy to Handle the Inhibiting Factors on Possibility of Applying Risk Management in Village Fund Management in Landak

3. Regency, West Kalimantan Province (Study on Office of Social Service, Community

Empowerment and Village Administration) (Nurman. 2015).

Source: 1) Fone and Young, Public Sector Risk Management (2001); 2) Robbins and Judge, Organizational Behavior (2013); 3) Nurman, Strategi Pembangunan Daerah (Regional Development Strategy) (2015).

maker that decide the application of risk management in village fund management in Landak Regency. Furthermore, informants are divided into two groups, i.e. main informants and supporting informants. Main informants are the ones 
with relation to focus of the study, and there are ideal main informant and standard main informant. And supporting informants are the ones with relation to locus of the study. Table 12 shows classification of informants.

In order to complement data in this study, related documents are required. Documentation technique is intended to obtain data directly from location of study, consisting of relevant books, regulations, activity reports, photos, documentary films, and other relevant data. Documents needed for information in this study refer to documents of Central Government and Local Government. Table 13 shows documents of Central Government and Local Government used as sources of information that are considered relevant under academic view.

\section{Result}

Result of study on possibility of applying risk management in village fund management can be concluded as follows:

1) The conclusion is based on theoretical basis, analysis of data on-site and result of interview on respondents in the study on possibility of applying risk management in village fund management in Landak Regency, West Kalimantan Province (study on office Of Social Service, Community Empowerment and Village Administration). Application of risk management is performed specifically by risk identification, risk analysis, and risk measurement. And then followed by building scenario in the implementation of risk management:

a) Risk Identification: In risk identification, there are two stages, i.e. a Comment on Risk Checklist and Sources of Information.

- A comment on Risk Checklist: risk in village fund management, namely problems in village fund management, is identified as follows: poor road

Table 12. Classification of informants.

\begin{tabular}{ll}
\hline \multicolumn{1}{c}{ Ideal main informant } & \multicolumn{1}{c}{ Standard main informant } \\
\hline \multicolumn{1}{c}{1} \\
\end{tabular}

Source: processed by author (2017). 
Table 13. Documents of central government and local government.

\begin{tabular}{cc}
\hline Documents of Central Government & Documents of Local Government \\
\hline 1 & 2 \\
\hline
\end{tabular}

1) Law No. 6 on Village

2) GR No. 60 of 2008 on Internal System

3) GR No. 72 of 2005 on Village

4) GR No. 43 of 2014 on Implementing

Regulation of Law No. 6 of 2014 on Village

5) GR No. 60 of 2014 on Village Fund sourced

from State Budget

6) GR No. 165 of 2014 on Arrangement of Duties and Functions of Working Cabinet

7) GR No. 11 of 2015 on Ministry of Home Affairs

8) GR No. 12 of 2015 on Ministry of Villages,

Disadvantaged Regions and Transmigration

9) Gr No. 22 of 2015 on Amendment of

Government Regulation No. 60 of 2014 on Villag Fund sourced from State Budget

10) Gr No. 47 of 2015 on amendment of GR No.

43 of 2014 on Implementing Regulation of Law

No. 6 of 2014 on Village

11) GR No. 16 of 2016 on Local Agencies

12) Regulation of Minister of Home Affairs No.

112 of 2014 on Village Chief Election

13) Regulation of Minister of Home Affairs No.

113 of 2014 on Village Financial Management

14) Regulation of Minister of Home Affairs No.

114 of 2014 on Guidelines for Village

Development

15) Regulation of Minister of Villages,

Disadvantaged Regions and Transmigration No.

of 2015 on Village Assistant

16) Regulation of Minister of Villages,

Disadvantaged Regions and Transmigration No. 5 of 2015 on Priorities in the Use of Village Fund

17) Regulation of Minister of Finance No.

241/PMK.07/2014 on Implementation and

Accountability of Fund Transfer to Regions and

Village Fund

18) Regulation of Minister of Finance No.

250/PMK.07/2014 on Allocation of Transfer to

Regions and Village Fund

1) RR No. 18 of 2016 on Second Amendment of RR No. 9 of 2008 on Local Bureaucracy

2) RR No. 11 of 2008 on RPJPD of Landak

Regency, 2007-2027

3) RR No. 9 of 2012 on RPJMD, 2012-2016

4) RR No. 12 of 2013 on Local Budget, 2014

5) RR No. 2 of 2014 on Amendment of Local

Budget 2014

6) RR No. 4 of 2014 on Local Budget, 2015

7) RR No. 1 of 2015 on $R T R W, 2014-2034$

8) RR No. 8 of 2015 on Accountability of

Implementation of Local Budget 2014

9) RR No. 9 of 2015 on Amendment of Local Budget 2015

10) RR No. 18 of 2015 on Local Budget, 2016

11) Regulation of Regent No. 3 of 2016 on

Guidelines for Village Financial Management

12) Work Plan of Office of Social Service,

Community Empowerment and Village

Administration

13) LAKIP of Office of Social Service,

Community Empowerment and Village

Administration

14) LKPJ of Office of Social Service, Community Empowerment and Village Administration

15) $L P P D$ of Office of Social Service,

Community Empowerment and Village

Administration

16) ILPPD of Office of Social Service,

Community Empowerment and Village

Administration

17) Strategic Plan of Office of Social Service,

Community Empowerment and Village

Administration

18) Statistics Indonesia of Landak Regency

19) Regulation of Minister of Finance No.

93/PMK.07/2015 on Procedures for Allocation,

Distribution, Use, Control and Evaluation of

Village Fund

facilities, limited facility of vehicle for mobility to implement official duties, limited office facilities and infrastructures, limited budget of local bureaucracy, low quantity and quality of human resources, poor understanding of the leader regarding village fund management, lack of information received by community regarding the use of village fund thus the control is weak, regular changes of regulation thus hindering the implementation, lack of regula- 
tion that technically regulates village fund management, low initiative from member of DPRD in the making of local regulation, and misappropriation of village fund by several village officials.

- Sources of information: information on risk in village fund management can be obtained by document analysis (financial report, condition of human resources, rules and regulations), monitoring and observation, and interview with informants.

b) Risk analysis: analysis of risk in village fund management through the risk chain, namely:

- Poor road facilities, limited facility of vehicle for mobility to implement official duties, limited office facilities and infrastructures are risks that occur in physical asset and are disadvantages for organization. Impacts of these risks are hindered delivery process of document which serves as information in the use of village fund, limited mobility in performing control function towards the use of village fund, and hindered process of village fund management due to limited supporting facilities. Without prompt counteraction, these risks can hinder village development, disbursement of village fund, and distribution of goods and services. In addition, parties related to village fund management will have difficulty to control the use of village fund in 156 villages. Thus, administration of village fund management will be hindered.

- Limited budget of Local Bureaucracy is a risk that occur in financial asset and is a disadvantage for organization. The impact is that several important activities can not be implemented to support village fund management. If this is not to be responded, the consequence is that programs and activities that have been planned will not be able to be held.

- Low quantity and quality of human resources, poor understanding of the leader regarding village fund management, lack of information received by community regarding the use of village fund, thus the control is weak, are risks that occur in asset of human resources and are disadvantages for organization. The impact resulted from these risks is that the making of RPJMDes, RKPDes, and Village Budget (APBDes) will not be in line with the needs of village community. Further impact is that low innovation on the issue of village fund, rampant misappropriation and no control from community will be most likely to happen. The consequences are, if these risks are not to be responded, that the making of planning documents and data will deviate from the standard and quality of the documents will decrease. Also, policies that are not in line with prioritized use of village fund according to rural areas, and no transparency on the needs of village community.

- Regular changes of regulation thus hindering the implementation, minimum regulation that technically regulates village fund management, low initiative from member of $D P R D$ in the making of local regulation are the risks that occur from regulation and are disadvantages for organization. The impacts are that no legal basis to support village fund management and uncertainty in the implementation of village fund management. The consequences are, if 
these are not to be responded, that there will be confusion among village officials regarding programs and activities that have been planned, and no guidelines in the implementation, thus resulting in administrative error.

- Misappropriation of village fund by several village officials is the risk that occur from individual morality and is a disadvantage for organization. The impact is that village development will be hindered. The consequence is, if this is not to be responded, that it will create new corrupt persons who misappropriate village fund.

c) Risk Measurement: there are several stages in risk measurement.

- Hidden costs/benefits of losses and gains: issues that are most likely to occur in village fund management is limited quality and quantity of human resources, limited facilities and infrastructures, lack of regulation, and limited availability of budget for activities.

- Dimensions of Exposure to Risk

$\checkmark$ Risks with highest frequency and that cause major losses are: limited quantity and quality of human resources, limited budget of $S K P D$, poor road infrastructures, limited office facilities and infrastructures, and corruption of budget by village officials thus hindering the village development.

$\checkmark$ Risks with average frequency and that cause medium losses are: unavailable regional regulation that technically regulates village fund management, low initiative from member of $D P R D$ in the making of local regulation regarding most recent issues on village fund management, regular changes of regulation thus hindering the implementation, lack of information received by community regarding the use of village fund, limited facility of vehicle for mobility to implement official duties.

$\checkmark$ Risk with low frequency and that causes minimum losses are: Poor understanding of the leader regarding village fund management.

- A brief comment on frequency and magnitude measurement terminology

$\checkmark$ Definite: poor road infrastructures, limited facility of vehicle for mobility to implement official duties, limited office facilities and infrastructures, limited budget of local bureaucracy $(O P D)$, limited quality of human resources both at village and in $O P D$, and minimum quantity of human resources that disrupt the process of village fund management.

$\checkmark$ Moderate: poor understanding of the leader regarding village fund management, lack of information received by community regarding the use of village fund thus the control is weak, regular changes of regulation thus hindering the implementation, lack of regulation that technically regulates recent issues on village fund management, and misappropriation of village fund by several village officials thus hindering village development.

$\checkmark$ Slight: Low initiative of $D P R D$ in making regional regulation regarding recent issues on village fund management.

Risk management is possible to apply when there is regulation and clear standard operating procedure, increased number and capacity of human resources, 
sufficient budget to implement risk management activities, and proper facilities and infrastructures for apparatus in Office of Social Service, Community Empowerment and Village Administration (DSPMPD) of Landak Regency, and by performing promotion, technical guidance, and training and education to provide government agencies with sufficient knowledge and understanding.

2) Supporting and inhibiting factors on possibility of applying risk management in village fund management in Landak Regency, West Kalimantan Province (Study on Office of Social Service, Community Empowerment and Village Administration).

a) Supporting Factors: Supporting factor in applying risk management is political development. Leadership change due to political development becomes driver of the implementation of risk management, as it potentially results in transfer of employee which eventually can have impact on the administration of government, specifically on village fund management. With risk management, despite of there is transfer of employee by leader, new officials should not be worried because track record in form of risk report is available that enable them to determine and analyze risks that frequently occur in order to find required follow-up action.

b) Inhibiting Factors

- Individual resistance: the inhibiting factor in individual resistance is habit. Habit is action conducted regularly towards same thing and is recognized by people. Due to habit, when confronted to risk management which is a new thing considered as an extra duty, individual will tend to resist.

- Organizational resistance: inhibiting factor in organizational resistance that hinder the application of risk management is group inertia. Group inertia may occurs when individual wants to change management by applying new system that bring advantage to organization. However, group in the organization tends to disagree with the change due to various reasons, and thus individual will tend to agree with resistance of the group and fails to apply the new issue, i.e. risk management.

3) Strategy to handle the inhibiting factors on possibility of applying risk management in village fund management in Landak Regency, West Kalimantan Province (Study on Office of Social Service, Community Empowerment and Village Administration).

\section{a) Top-Down Approach}

Strategy in top-down approach is to support from local government in form of programs and budget for improvement of human resources and arrangement of regulations to enable policy making and to have proper quality of human resources of apparatus. With programs and availability of budget, new policies can be made regarding administrative issues, i.e. risk management, either in form of regent regulation or regional regulation so that the risk management for village fund management can be performed well.

b) Bottom-Up Approach 
Strategies in bottom-up approach are to make regulations and clear standard operating procedure, to make available of budget, to increase quantity and quality of human resources, to improve facilities and infrastructures, and to conduct control and monitoring on the application of risk management

\section{Recommendation}

Based on result above, author would like to give several recommendations as part of brainstorming for government to make policy in relation with possibility of applying risk management in village fund management.

1) The conclusion is based on theoretical basis, analysis of data on-site and result of interview on respondents in the study on possibility of applying risk management in village fund management in Landak Regency, West Kalimantan Province (study on office of Social Service, Community Empowerment and Village Administration). Application of risk management is performed specifically by risk identification, risk analysis, and risk measurement. And then followed by building scenario in the implementation of risk management:

a) Risk Identification:

- A comment on risk checklist: Identifying risks by making risk checklist regarding the village fund management using brainstorming group and workshops.

- Sources of information: Sources of risk can not only be seen from sources of information, namely analysis of documents (financial report, condition of human resources, rules and regulations), monitoring and observation, and interview with informants, but also form statistical data of village development, consultation place for risk management, and the community who observes the risks.

b) Risk Analysis. In analyzing the risks that may occur in village fund management through risk chain, it is necessary to perform more detailed risk analysis using probability matrix along with risk level to facilitate the analysis of risk with impact of major loss and with consequences that are easier to analyze.

c) Risk Measurement

- Hidden costs/benefits of losses and gains: author recommends having good management of human resources, improvement of facilities and infrastructures, especially village hall, and acceleration of process of regulation-making.

- Dimensions of exposure to risk: author recommends promptly accommodating risks that regularly occur with major losses through improvement of capacity of human resources, application of good management of human resources, establishment of revenue sources by establishing Village-Owned Enterprises (BUMDes) and mapping of revenue sources, planning of road repairs and improvement of facilities and infrastructures, and control towards village officials.

- A brief comment on frequency and magnitude measurement terminology: More advanced risk measurement is needed by using probability distribution (qualitative description on frequency of the risks), risk sensitiveness is meas- 
ured based on how sensitive an exposure to change of certain factor, determining the maximum value at risk, and making a frequency matrix to facilitate the determination of frequency level of risks and major losses.

This study on risk management needs more advanced and more detailed research because, here, author limits the scope only on risk assessment since it has not been conducted in Landak Regency. In addition, local government should make regulation as basis for application of risk management in every local bureaucracy, so that every decision will consider risks that may occur. Specific on village fund management, it should be integrated directly in Village Financial System Application to facilitate village officials in determining risks according to problems that every village faces, and eventually to make policy to handle the risks.

2) Supporting and inhibiting factors in the study on possibility of applying risk management in village fund management in Landak Regency, West Kalimantan Province (Study on Office of Social Service, Community Empowerment and Village Administration).

a) Supporting Factors

Commitment of leader is needed in application of risk management, by making regent regulation, so that impact of the risks in village fund management can be determined.

b) Inhibiting Factors

- Individual Resistance

To handle individual resistance against application of new thing, it is necessary to change the behavior and perspective by giving reward and punishment so that there always be consequences in each duty.

- Organizational Resistance

To handle group resistance, it needs to share the perspective to apparatus that innovation is needed in order to enable government organization to always provide best public services by administrating government appropriately.

3) Strategy to handle the inhibiting factors on possibility of applying risk management in village fund management in Landak Regency, West Kalimantan Province (Study on Office of Social Service, Community Empowerment and Village Administration).

a) Top-Down Approach

Giving recommendation to leader that application of risk management is good for taking all necessaries based on risks that occur and losses resulted from the risks.

b) Bottom-Up Approach

Giving support to the bottom level to consider interaction between related organizations, aspect of interaction and relationship between government and community, and to be able to implement public interest based on the risks.

\section{Conflicts of Interest}

The authors declare no conflicts of interest regarding the publication of this paper. 


\section{References}

[1] Relianus, K. (2016) Problems in Management of Village Finances. http://kupang.tribunnews.com/2016/04/08/masalah-pengelolaan-keuangan-desa?pa ge=all

[2] Ministry of Villages, Disadvantaged Regions and Transmigration (2017) Rural Development Policy. Ministry of Villages, Disadvantaged Regions and Transmigration, Jakarta.

[3] Medistiara, Y. (2017) ICW States That Most Cases of Village Fund Corruption Are Done by Village Chiefs.

https://news.detik.com/berita/d-3596041/icw-sebut-pak-kades-paling-banyak-koru psi-dana-desa

[4] AB/YK/N-1 (2017) 212 Village Chiefs Are Suspected in Village Fund Corruption Cases.

http://mediaindonesia.com/read/detail/130898-212-kepala-desa-jadi-tersangka-kas us-dana-desa

[5] Krisno, O. (2017) Accountability Report of Village Fund Allocation in Landak Is Behind Schedule.

https://daerah.sindonews.com/read/1254244/174/laporan-pertanggungjawaban-add -di-landak-tidak-tepat-waktu-1509704865

[6] Dede (2016) Village Apparatus of Landak Regency Have Not Received Village Fund and Village Fund Allocationx.

http://thetanjungpuratimes.com/2016/05/31/pihak-desa-di-kabupaten-landak-belu $\underline{\text { m-terima-dana-add-dan-dd }}$

[7] Comelius, H. (2017) District Attomey Denies Dialog with Ditrict Head and Village Chief regarding the Case.

http://pontianak.tribunnews.com/2017/08/24/kajari-bantah-dialog-bersama-camatdan-kades-terkait-kasus-ini-sebenarnya-yang-dibahas?page $=2$

[8] Kasidi (2014) Risk Management. Ghalia Indonesia, Semarang.

[9] Ministry of Home Affairs (2008) Regulation of Government of the Republic of Indonesia No. 60 of 2008 on Government Internal Control System. Indonesia, Regulasi.

[10] Regulation of Minister of Home Affairs of the Republic of Indonesia No. 113 of 2014 on Village Financial Management. Indonesia, Regulation.

[11] Muis, A. (2015) Policy Paper on Village Financial Management Following Law No. 6 of 2014. Pusat Intan LAN, Jakarta.

[12] Dede (2016) Landak Regency Government Facilitates Villages Apparatus to Prepare Village Budget.

http://thetanjungpuratimes.com/2016/07/20/pemkab-landak-fasilitasi-perangkat-de sa-menyusun-apbdes.

[13] Conecting Road Betwem Two Villages in Landak Is Heavily Damaged. http://thetanjungpuratimes.com/2016/04/24/jalan-penghubung-dua-desa-di-landak -rusak-parah

[14] Landak Regency (2014) Regional Regulation of Landak Regency No. 4 of 2014 on Local Budget of Landak Regency of 2015. Regulation, Landak.

[15] Regional Regulation of Landak Regency No. 18 of 2015 on Local Budget of Landak Regency of 2016. Regulation, Landak.

[16] Wasistiono, S. (2002) Selected Topics on Management of Local Administration. Alqaprint, Jatinangor. 
[17] Wedhaswary, I.D. (2014) "Nawa Cita", the 9 Priorities of Jokowi-JK. https://nasional.kompas.com/read/2014/05/21/0754454/Nawa.cita.9.Agenda.priorit as.Jokowi.JK

[18] Stability (2016) Even Government Needs Risk Management. Http://stabilitas.co.id/home/detail/pemerintah-pun-perlu-manajemen-risiko

[19] Young, P. and Fone, M. (2001) Public Sector Risk Management. Butterworth, Heinemann.

[20] Ministry of Home Affairs (2014) Law No. 6 of 2014 on Village. 6 Indonesia. Regulation.

[21] Ministry of Home Affairs (2014) Government Regulation No. 60 of 2014 on Village. Indonesia. Regulation.

[22] Fakpahan, A. (2017) Development Strategy: Developing from Peripheral Regions. http://kalimantan.bisnis.com/read/20171030/251/703767/strategi-pembangunan-m embangun-dari-pinggiran

[23] Comelius, H. (2017) Attorney Denies Dialog with District Head and Village Chief Regarding the Case.

http://pontianak.tribunnews.com/2017/08/24/kajari-bantah-dialog-bersama-camatdan-kades-terkait-kasus-ini-sebenarnya-yang-dibahas?page $=2$

[24] Robbins and Judge (2013) Organizational Behavior. Prentice Hall, Upper Saddle River.

[25] Nurman (2015) Regional Development Strategy. Rajagrafindo Persada, Jakarta.

[26] Landak Regency (2015) Regional Regulation of Landak Regency No. 5 of 2016 on Formation and Structure of Local Agencies of Landak Regency. 5 Landak Indonesia. Regulation.

[27] Minister of Finance of the Republic of Indonesia (2015) Regulation of Minister of Finance of the Republic of Indonesia No. 93/PMK.07/2015 on Procedures for Allocation, Distribution, Use, Control and Evaluation of Village Fund. Indonesia. Regulation.

[28] Simangunsong, F. (2014) Organization Transformation: Status Change from Administrative Village to Sub-District. Alfabeta, Bandung.

[29] Chermack, T.J. (2011) Scenario Planning in Organizations. Berret-Koehler, Oakland.

[30] Aryani, D. (2012) Dissertation on Scenario of Policy on Energy in Indonesia until 2035. Universitas Indonesia, Depok.

[31] Neuman, W.L. (2003) Social Research Method Qualitative and Quantitative Approaches. Allyn and Bacon, Boston.

[32] Simangunsong, F. (2017) Research Methodology of Public Administration. Alfabeta, Bandung. 